\title{
Improvement of airflow limitation by fluticasone propionate/salmeterol in chronic obstructive pulmonary disease: what is the specific marker?
}

\section{Keiichiro Akamatsu, Kazuto Matsunaga, Hisatoshi Sugiura, Akira Koarai, Tsunahiko Hirano, Yoshiaki Minakata and Masakazu Ichinose*}

Third Department of Internal Medicine, School of Medicine, Wakayama Medical University, Wakayama, Japan

\author{
Edited by: \\ Pascal Chanez, Université de la \\ Mediterranée, France \\ Reviewed by: \\ Pascal Chanez, Université de la \\ Mediterranée, France \\ Massimo Corradi, University of \\ Parma, Italy \\ *Correspondence: \\ Masakazu Ichinose, Third Department \\ of Internal Medicine, School of \\ Medicine, Wakayama Medical \\ University, 811-1 Kimiidera, \\ Wakayama 641-8509, Japan. \\ e-mail: masakazu@wakayama- \\ med.ac.jp
}

\begin{abstract}
Backgrounds: Inhaled corticosteroids (ICS)/inhaled long-acting beta 2 -agonists (LABA) combination drugs are widely used for the long-term management of chronic obstructive pulmonary disease (COPD). However, COPD is a heterogeneous condition and treatment with ICS is associated with a higher risk of pneumonia. The identification of a specific marker for predicting the efficacy of ICS/LABA on pulmonary function would be useful in the treatment of COPD. Methods: Fourteen COPD patients receiving tiotropium therapy participated consecutively. The relationship between the baseline exhaled nitric oxide ( $\mathrm{FE}_{\mathrm{NO}}$ ) levels as well as serum markers and changes in pulmonary function by fluticasone propionate (FP)/salmeterol (SAL) were analyzed. Results: FP/SAL therapy significantly improved forced vital capacity, forced expiratory volume in $1 \mathrm{~s}\left(\mathrm{FEV}_{1}\right)$, and the third phase slope of the single nitrogen washout curve $\left(\Delta N_{2}\right)$ as well as the $F E_{N O}$ level. The baseline $F E_{N O}$ levels and positive specific lgE (atopy + ) were significantly associated with airway obstructive changes assessed by FEV 1 and $\Delta \mathrm{N}_{2}$. A baseline $\mathrm{FE}_{\mathrm{NO}}$ level $>35 \mathrm{ppb}$ yielded $80.0 \%$ sensitivity and $66.7 \%$ specificity for identifying the subjects with significant improvement in FEV 1 (greater than $200 \mathrm{~mL}$ ). An atopy+ yielded $60.0 \%$ sensitivity and $88.9 \%$ specificity for an improvement in $\mathrm{FEV}_{1}$. When combined with $\mathrm{FE}_{\mathrm{NO}}>35 \mathrm{ppb}$ and atopy+, it showed $40 \%$ sensitivity and $100.0 \%$ specificity for $\mathrm{FEV}_{1}$ improvement. Alternatively, COPD subjects with $\mathrm{FE}_{\mathrm{NO}} \leq 35 \mathrm{ppb}$ and atopy- did not show significant improvement in $\mathrm{FEV}_{1}$. Conclusion: Combining $\mathrm{FE}_{\mathrm{NO}}$ and specific IgE may be a useful marker for predicting the response to ICS/LABA on airflow limitation in COPD.
\end{abstract}

Keywords: airflow limitation, airway inflammation, atopy, exhaled nitric oxide, inhaled corticosteroid, inhaled

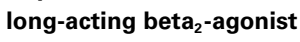

\section{INTRODUCTION}

Chronic obstructive pulmonary disease (COPD) is a chronic pulmonary inflammatory disorder, and pathological changes are observed in the proximal airways, peripheral airways, lung parenchyma, and pulmonary vasculature. These inflammatory and structural changes lead to various physiological changes in lung function, including airflow limitation, air trapping, ventilation heterogeneity, and gas exchange abnormalities (Rabe et al., 2007).

In the long-term management of stable COPD, long-acting bronchodilators are central to the pharmacologic treatment (Celli and MacNee, 2004; Rabe et al., 2007). The use of inhaled corticosteroids (ICS) is recommended to reduce the frequency of exacerbations in symptomatic patients with a forced expiratory volume in $1 \mathrm{~s}\left(\mathrm{FEV}_{1}\right)$ of less than $50 \%$ of predicted and repeated exacerbations (Mahler et al., 2002; Calverley et al., 2003; Jones et al., 2003; Szafranski et al., 2003; Spencer et al., 2004). To date, the

Abbreviations: $\mathrm{FE}_{\mathrm{NO}}$, exhaled nitric oxide fraction; $\mathrm{FP}$, fluticasone propionate;

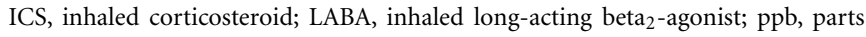
per billion; SAL, salmeterol. effectiveness of ICS for patients with COPD remains controversial (Pauwels et al., 1999; Vestbo et al., 1999; Burge et al., 2000; Lung Health Study Research Group, 2000). Recently, ICS/inhaled long-

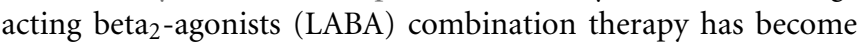
widely used in clinical practice, achieving profound improvements of pulmonary function, symptoms and health-related quality of life, and preventing exacerbations compared with placebo or either monotherapy alone (Mahler et al., 2002; Calverley et al., 2003, 2007; Hanania et al., 2003; Szafranski et al., 2003; Wedzicha et al., 2008). However, a meta-analysis has clarified that the efficacy of ICS/LABA combination therapy compared with LABA monotherapy on pulmonary function shows statistical heterogeneity (Rodrigo et al., 2009). In addition, ICS therapy may lead to increased risk of pneumonia in the patients with COPD (Drummond et al., 2008; Wedzicha et al., 2008; Rodrigo et al., 2009; Singh et al., 2009). These findings strongly suggest that it is important to clarify a clinical marker that has high specificity for identifying COPD patients for whom ICS/LABA combination would be beneficial. Importantly, the effects of ICS in COPD are much less dramatic than in asthma and the long-term safety of ICS in patients with COPD is not well established. 
The aim of this study was to assess a specific marker for predicting the efficacy of ICS/LABA combination therapy for pulmonary function. We investigated the relationship between the baseline levels of $\mathrm{FE}_{\mathrm{NO}}$, serum markers, and changes in pulmonary function by additive treatment of fluticasone propionate (FP)/salmeterol (SAL) combination to tiotropium.

\section{MATERIALS AND METHODS STUDY SUBJECTS}

Fourteen stable COPD patients receiving long-acting muscarinic receptor antagonist (tiotropium $18 \mu \mathrm{g} /$ day) were consecutively enrolled from the outpatient clinic of Wakayama Medical University Hospital. COPD was diagnosed according to the guidelines of the Global Initiative for Chronic Obstructive Lung Disease (Rabe et al., 2007). All subjects had airflow limitation with $\mathrm{FEV}_{1}<80 \%$ of predicted and $\mathrm{FEV}_{1}$ /forced vital capacity (FVC) ratio $<70 \%$. They had a smoking history of more than 10 pack-years and had emphysema on high-resolution computed tomography (HRCT) of the lungs. Current smokers were excluded because of the influence of smoking on the exhaled nitric oxide $\left(\mathrm{FE}_{\mathrm{NO}}\right)$ levels (McSharry et al., 2005). Subjects who had histories and symptoms of atopic rhinitis, chronic rhinosinusitis, atopic dermatitis, food allergy, asthma, or other lung diseases were carefully excluded from the study. Those who had an exacerbation of COPD in the 4-weeks preceding the study were not included. Rescue use of salbutamol (200 $\mu \mathrm{g}$ as needed) for symptom relief was allowed. The study subjects who had been using LABA, ICS, ICS/LABA combination, oral beta $_{2}$-agonists, regular use of inhaled short-acting beta ${ }_{2}$-agonists, regular use of inhaled, short-acting muscarinic receptor antagonists, and slow release theophylline were not allowed such use for at least 4 weeks before and during the study. The protocol was approved by the local ethics committee and performed after written informed consent was obtained from each subject.

\section{STUDY DESIGN}

Pulmonary function test, $\mathrm{FE}_{\mathrm{NO}}$ measurement, blood sampling, and HRCT of lungs were performed on the first visit. After assessment of the baseline values, FP/SAL $(250 / 50 \mu \mathrm{g})$ was added twice daily for 12 weeks, and then pulmonary function test and $\mathrm{FE}_{\mathrm{NO}}$ measurement were repeated. These variables were measured 2-4 h prior to the dosing of tiotropium and FP/SAL (Figure 1).

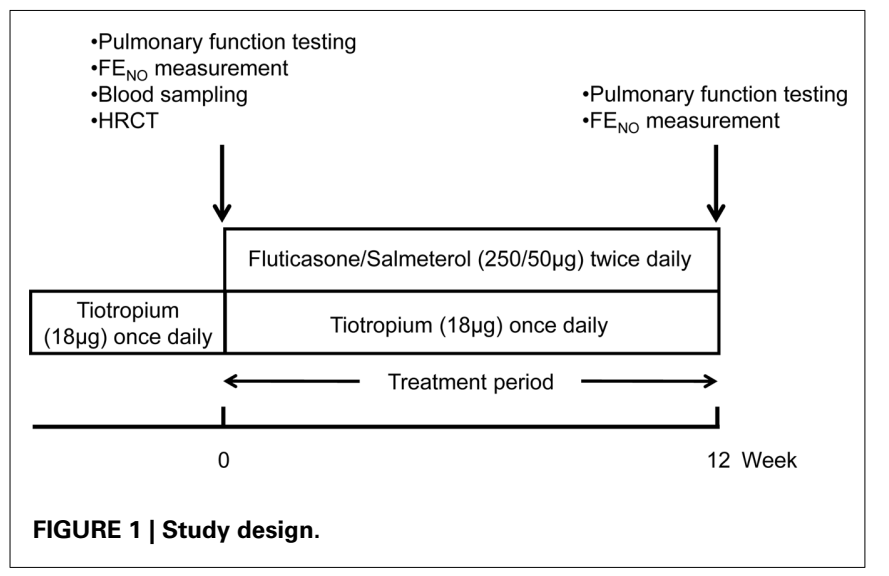

\section{PULMONARY FUNCTION TESTING}

Forced vital capacity, $\mathrm{FEV}_{1}$, forced expiratory flow (FEF), slope of the single breath nitrogen washing curve $\left(\Delta \mathrm{N}_{2}\right)$, total lung capacity (TLC), residual volume (RV), and diffusion lung carbon monoxide (DLCO) were evaluated using a dry rolling seal spirometer (CHESTAC-8800; Chest, Inc., Tokyo, Japan).

\section{EXHALED NO MEASUREMENT}

$\mathrm{FE}_{\mathrm{NO}}$ was measured in accordance with the current guidelines (ATS/ERS, 2005) using a chemoluminescence analyzer (modified NA-623N ${ }^{\oplus}$; Chest, Inc., Tokyo, Japan). Exhalations were repeated to obtain two acceptable values that agreed within $10 \%$ deviation, and the average of these two values was registered. All subjects were fasted for $1 \mathrm{~h}$ before the measurements.

\section{BLOOD SAMPLING}

C-reactive protein (CRP), complete blood cell count, differential count of leukocytes, total serum immunoglobulin E (IgE) levels, and specific IgE for common allergens including Dermatophagoides pteronyssinus (DP), Dermatophagoides farina (DF), house dust 1 (HD1), house dust 2 (HD2), were examined. Positive specific IgE to at least one allergen was assumed to confirm a diagnosis of atopy.

\section{STATISTICAL ANALYSIS}

Statistical analysis of changes in pulmonary function and $\mathrm{FE}_{\mathrm{NO}}$ were assessed using Wilcoxon signed-ranks test. Spearman's rank correlations were calculated to determine the relative changes between physiologic parameters and continuous data (eosinophil cell counts, total serum IgE, and $\mathrm{FE}_{\mathrm{NO}}$ values). Comparison between atopic and non-atopic subjects was made by MannWhitney $U$-tests. The results are presented as mean $\pm \mathrm{SE}$. A value of $p<0.05$ was considered to be significant.

\section{RESULTS}

The baseline characteristics are listed in Table 1. All subjects were ex-smokers, and males were over-represented. The majority $(65 \%)$ of the study subjects was stage 2 , four were stage 3 and one was stage 4 . The mean $\mathrm{FE}_{\mathrm{NO}}$ level was $36.4 \mathrm{ppb}$, and

Table 1 | Baseline characteristics of the study subjects.

\begin{tabular}{ll}
\hline Number (female/male) & $\mathbf{1 4}(\mathbf{2 / 1 2})$ \\
\hline Age (years) & $70.0 \pm 5.2$ \\
Body mass index $\left(\mathrm{kg} / \mathrm{m}^{2}\right)$ & $22.7 \pm 1.9$ \\
Pack years (years) & $52.7 \pm 8.5$ \\
GOLD classification (stage2/stage3/stage4; $n)$ & $9 / 4 / 1$ \\
$\mathrm{FE}_{\mathrm{NO}}(\mathrm{ppb})$ & $36.4 \pm 4.7$ \\
White blood cells $(/ \mu \mathrm{L})$ & $5158 \pm 274$ \\
Blood Eosinophils $(/ \mu \mathrm{L})$ & $158 \pm 38$ \\
C-reactive protein $(\mathrm{mg} / \mathrm{DI})$ & $0.13 \pm 0.05$ \\
Immunoglobulin E RIST $(\mathrm{IU} / \mathrm{mL})$ & $170.6 \pm 47.5$ \\
Immunoglobulin E RAST for DP/DF/HD $(n)$ & $4 / 3 / 4$
\end{tabular}

GOLD, Global Initiative for Chronic Obstructive Lung Disease; $F E_{N O}$, fraction of exhaled nitric oxide; DP, Dermatophagoides pteronyssinus; DF, Dermatophagoides farina; $H D$, house dust. All values are mean $\pm S E$. 
Table 2 | Lung function and exhaled nitric oxide before and after treatment with inhaled fluticasone/salmeterol combination.

\begin{tabular}{|c|c|c|c|c|}
\hline & Before & After & Difference (range) & $p$-value \\
\hline FVC (L) & $2.99 \pm 0.17$ & $3.12 \pm 0.19$ & $0.15(-0.15$ to 0.64$)$ & $<0.05$ \\
\hline \%FVC (\%) & $93.0 \pm 4.2$ & $96.1 \pm 4.9$ & $3.1(-5.2$ to 15.9$)$ & 0.16 \\
\hline $\mathrm{FEV}_{1} / \mathrm{FVC}(\%)$ & $51.4 \pm 3.8$ & $54.3 \pm 3.9$ & $2.9(-3.1$ to 16.6$)$ & 0.16 \\
\hline$\% \mathrm{FEV}_{1}(\%)$ & $57.6 \pm 4.4$ & $62.0 \pm 3.6$ & $4.4(-8.7$ to 15.9$)$ & $<0.05$ \\
\hline \%TLC (\%) & $100.1 \pm 0.3$ & $105.8 \pm 0.3$ & $5.7(-6.6$ to 32.9$)$ & 0.11 \\
\hline$\%$ RV (\%) & $120.1 \pm 14.7$ & $112.8 \pm 15.2$ & $-7.3(-78.1$ to 64.3$)$ & 0.55 \\
\hline$\Delta N_{2}(\%)$ & $3.07 \pm 0.36$ & $2.44 \pm 0.24$ & $-0.6(-2.6$ to 0.8$)$ & $<0.05$ \\
\hline$\% \mathrm{DL} \mathrm{CO}_{\mathrm{A}} / \mathrm{V}_{\mathrm{A}}(\%)$ & $64.9 \pm 7.8$ & $67.4 \pm 7.7$ & $2.6(-10.7$ to 17.6$)$ & 0.35 \\
\hline $\mathrm{FE}_{\mathrm{NO}}(\mathrm{ppb})$ & $36.4 \pm 4.7$ & $23.9 \pm 3.6$ & $-12.5(-52.2$ to 4.4$)$ & $<0.05$ \\
\hline
\end{tabular}

FVC, forced vital capacity; $F E V_{1}$, forced expiratory volume in $1 \mathrm{~s}$; FEF, forced expiratory flow; $T L C$, total lung capacity; $R V$, residual volume; $\triangle N_{2}$, slope of the single breath nitrogen washing curve; $D L_{C O}$, diffusion lung carbon monoxide; $V_{A}$, alveolar volume; $F E_{N o}$, fraction of exhaled nitric oxide. All values are mean $\pm S E$.
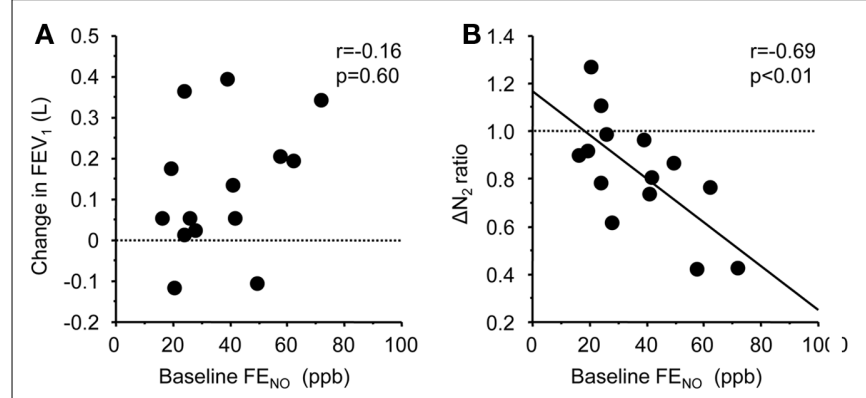

FIGURE 2 | Correlation between baseline levels of $\mathrm{FE}_{\mathrm{NO}}$ and FP/SAL-mediated changes in $\mathrm{FEV}_{1}(\mathrm{~A})$ and slope of the single breath nitrogen washing curve $\left[\Delta \mathbf{N}_{\mathbf{2}}(\mathbf{B})\right]$. The lines correspond to the fitted regression of the equation. Baseline $\Delta N_{2}$ values $/ \Delta N_{2}$ values after FP/SAL combination treatment was defined as $\Delta \mathrm{N}_{2}$ ratio.

four subjects were defined as having atopy. The mean $\mathrm{FE}_{\mathrm{NO}}$ levels were similar between the subjects with or without atopy (atopy+, $43.6 \mathrm{ppb}$; atopy-, $33.5 \mathrm{ppb} ; \mathrm{p}=0.63$ ). Table 2 shows the lung function and $\mathrm{FE}_{\mathrm{NO}}$ values before and 12-weeks after treatment with FP/SAL combination therapy. The treatment with FP/SAL significantly improved FVC, $\mathrm{FEV}_{1}, \% \mathrm{FEV}_{1}, \% \mathrm{FEF}_{75 \% \mathrm{FVC}}$, and $\Delta \mathrm{N}_{2}$ (all $p<0.05$ ). The median change of $\mathrm{FEV}_{1}$ was $0.13 \mathrm{~L}$ ranging from -0.11 to $0.40 \mathrm{~L}$. The mean $\mathrm{FE}_{\mathrm{NO}}$ level was also significantly reduced by the treatment with FP/SAL $(p<0.05)$.

The baseline $\mathrm{FE}_{\mathrm{NO}}$ level was not associated with the changes in $\mathrm{FEV}_{1}(r=-0.16, p=0.60)$, but significantly correlated with the changes in $\Delta \mathrm{N}_{2}(r=-0.69, p<0.01$; Figure 2$)$. The relationship between the baseline $\mathrm{FE}_{\mathrm{NO}}$ levels and the changes in other pulmonary physiological parameters were not significant. Among the serum markers, the subjects with positive specific IgE showed significantly higher improvement in $\mathrm{FEV}_{1}(p<0.05)$, but not in $\Delta \mathrm{N}_{2}$ (Figure 3). Other serum markers including blood eosinophils, CRP, and total IgE levels were not correlated with the changes in any physiological parameters.

From the previous results, the baseline $\mathrm{FE}_{\mathrm{NO}}$ levels and positive specific IgE were significantly associated with airway obstructive
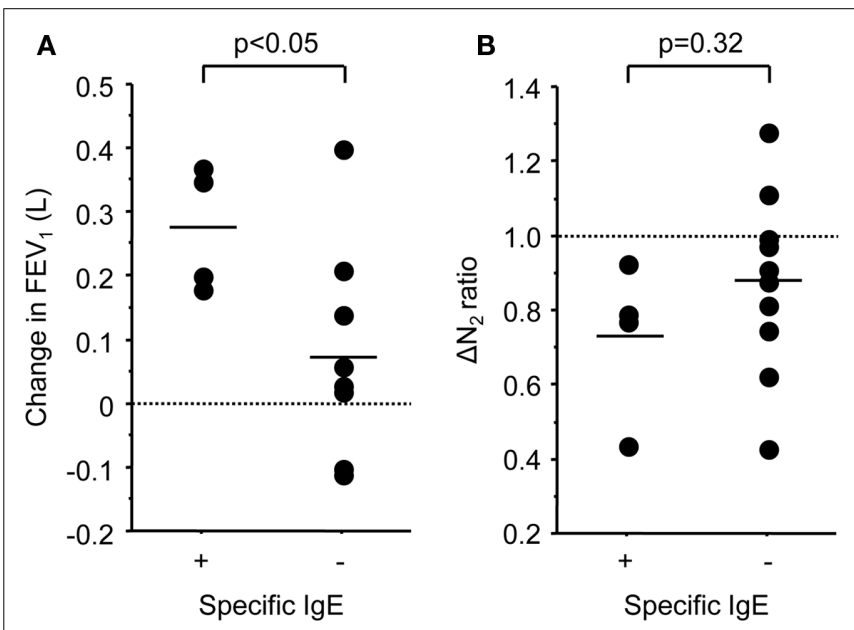

FIGURE 3 | Scatter plots of FP/SAL-mediated changes in FEV 1 (A) and slope of the single breath nitrogen washing curve $\left[\Delta N_{2}(B)\right]$ values in the subjects with positive or negative specific $\lg E$ results.

changes assessed by $\mathrm{FEV}_{1}$ and $\Delta \mathrm{N}_{2}$. Therefore, $\mathrm{FE}_{\mathrm{NO}}$ and atopy were selected and their sensitivity and specificity for predicting a significant improvement in $\mathrm{FEV}_{1}$ (greater than $200 \mathrm{~mL}$ ) were analyzed. The rationale for selecting $35 \mathrm{ppb}$ as a cutoff point for $\mathrm{FE}_{\mathrm{NO}}$ was based on previously reported upper reference ranges in $\mathrm{FE}_{\mathrm{NO}}$ in the Japanese adult population (Matsunaga et al., 2010). In our study, as shown in Table 3, 5 of 14 COPD subjects $(36 \%)$ showed a significant improvement in $\mathrm{FEV}_{1}$ by additive FP/SAL therapy. A baseline $\mathrm{FE}_{\mathrm{NO}}$ level $>35 \mathrm{ppb}$ yielded $80.0 \%$ sensitivity and $66.7 \%$ specificity for identifying the subjects with significant improvement in $\mathrm{FEV}_{1}$, with a positive predictive value (PPV) of $57.1 \%$ and negative predictive value (NPV) of $85.7 \%$. A positive result of specific IgE (atopy+) yielded $60.0 \%$ sensitivity and $88.9 \%$ specificity of an improvement in $\mathrm{FEV}_{1}$, with PPV of $75.0 \%$ and $\mathrm{NPV}$ of $80.0 \%$. When combined with $\mathrm{FE}_{\mathrm{NO}}>35 \mathrm{ppb}$ and atopy+, it showed $40 \%$ of sensitivity and $100.0 \%$ specificity, with a PPV of $100.0 \%$ and NPV of $75.0 \%$ for $\mathrm{FEV}_{1}$ improvement. Alternatively, 
COPD subjects with $\mathrm{FE}_{\mathrm{NO}} \leq 35 \mathrm{ppb}$ and atopy- did not show significant improvement in $\mathrm{FEV}_{1}$ by additive treatment of FP/SAL combination to tiotropium (Figure 4).

\section{DISCUSSION}

This is the first study to identify that combining $\mathrm{FE}_{\mathrm{NO}}$ and specific IgE appears to be a useful marker for predicting the response to ICS/LABA of airflow limitation in COPD. We demonstrated that $\mathrm{FVC}, \mathrm{FEV}_{1}$, and $\Delta \mathrm{N}_{2}$ values, as well as the $\mathrm{FE}_{\mathrm{NO}}$ levels, were significantly improved by additional treatment with FP/SAL. The increased $\mathrm{FE}_{\mathrm{NO}}$ levels at baseline and atopy+ were significantly associated with airway obstructive changes assessed by $\mathrm{FEV}_{1}$ and $\Delta \mathrm{N}_{2}$. Furthermore, COPD subjects with $\mathrm{FE}_{\mathrm{NO}} \leq 35 \mathrm{ppb}$ and atopy- did not show significant improvement in $\mathrm{FEV}_{1}$.

Use of ICS is recommended to reduce the frequency of exacerbations in symptomatic patients with a $\mathrm{FEV}_{1}$ of less than $50 \%$ predicted and repeated exacerbations (Mahler et al., 2002; Calverley et al., 2003; Jones et al., 2003; Szafranski et al., 2003; Spencer et al., 2004; Rabe et al., 2007). ICS/LABA combination therapy has obtained widespread acceptance in clinical practice. In the largest systematic review designed to assess the safety and efficacy of the regular use of ICS/LABA compared with the use of LABA alone in stable with moderate-to-very severe COPD, treatment with ICS/LABA significantly increased the risk of not only pneumonia, but also otopharyngeal candidiasis and viral respiratory infections (Rodrigo et al., 2009). Furthermore, a meta-analysis has clarified that the efficacy of ICS/LABA combination therapy compared with LABA monotherapy on pulmonary function showed statistical heterogeneity (Rodrigo et al., 2009). Therefore,

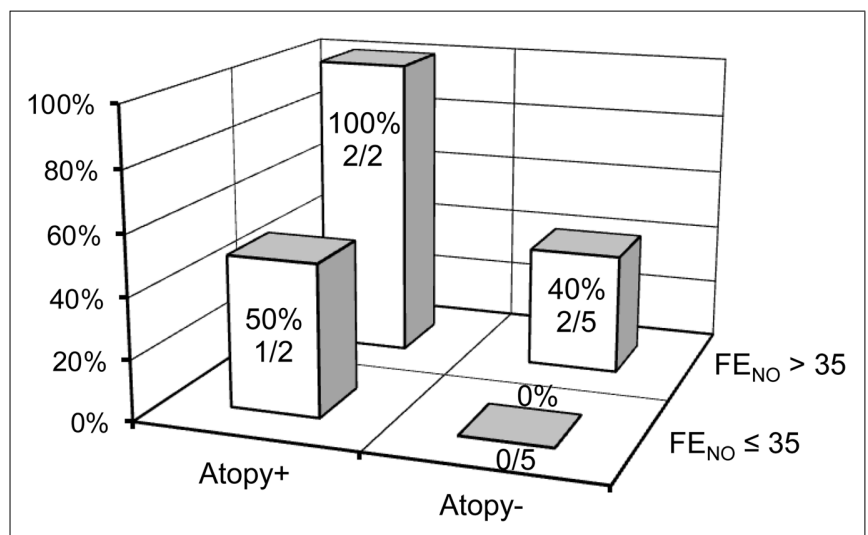

FIGURE 4 | Distribution of the subjects whose FEV $_{1}$ was increased greater than $12 \%$ by FP/SAL combination treatment stratified by baseline $\mathrm{FE}_{\mathrm{No}}$ level and specific IgE results. the identification of a specific marker for predicting the efficacy of ICS/LABA would be useful in the treatment of COPD.

We showed that the $\mathrm{FE}_{\mathrm{NO}}$ levels were significantly improved by the additional treatment with ICS/LABA. This finding is consistent with those of previous studies on steroid therapy in patients with COPD (Zietkowski et al., 2005; Kunisaki et al., 2008; Lehtimaki et al., 2010). Among patients with COPD, it has been proposed that steroid responsiveness is related to eosinophilic airway inflammation (Chanez et al., 1997). Several studies showed that the level of sputum eosinophils can predict the response to a short course of oral prednisolone or ICS in COPD (Pizzichini et al., 1998; Brightling et al., 2000, 2005; Leigh et al., 2006). Recently, one study showed that $\mathrm{FE}_{\mathrm{NO}}$ can predict the response to oral prednisolone (Dummer et al., 2009) and three studies showed that $\mathrm{FE}_{\mathrm{NO}}$ can predict the response to ICS in COPD (Zietkowski et al., 2005; Kunisaki et al., 2008; Lehtimaki et al., 2010). These results suggest that there is a subgroup with eosinophilic inflammation among COPD patients, and that the detection of eosinophilic inflammation could be useful for predicting the efficacy of steroid therapy.

In the present study, when $\mathrm{FE}_{\mathrm{NO}}$ was $>35 \mathrm{ppb}$, the sensitivity was 0.80 and the specificity was 0.67 for the subjects whose $\mathrm{FEV}_{1}$ was increased greater than $12 \%$ by FP/SAL combination treatment, although the baseline $\mathrm{FE}_{\mathrm{NO}}$ was not correlated with the changes in $\mathrm{FEV}_{1}$ after combined ICS/LABA. A relationship between the baseline $\mathrm{FE}_{\mathrm{NO}}$ levels and steroid-mediated changes in the pulmonary physiological parameters has been reported in several previous studies (Zietkowski et al., 2005; Kunisaki et al., 2008; Dummer et al., 2009; Lehtimaki et al., 2010). The baseline $\mathrm{FE}_{\mathrm{NO}}$ was a predictor of the increase in $\mathrm{FEV}_{1}$ by steroid therapy (Dummer et al., 2009), and high levels of bronchial NO flux were found to be related to symptom relief and improvement of the airway obstruction during treatment with inhaled fluticasone (Lehtimaki et al., 2010). The reason that the baseline $\mathrm{FE}_{\mathrm{NO}}$ was not correlated with the changes in $\mathrm{FEV}_{1}$ in our study may be due not only to the effect of ICS but also that of LABA. The results of these studies and ours suggested that the measurement of $\mathrm{FE}_{\mathrm{NO}}$ may enable the selection of individual COPD patients who could benefit from steroid therapy.

Interestingly, the present study showed a significant correlation between positive specific IgE and the degree of improvement in $\mathrm{FEV}_{1}$. Atopy was found to be associated with increased $\mathrm{FE}_{\mathrm{NO}}$ irrespective of asthma (Malinovschi et al., 2009) and is known to favor eosinophilic inflammation (Schleich et al., 2010). This is the first report showing that specific IgE is a useful marker to predict the efficacy of ICS/LABA combination in COPD patients. In contrast, the peripheral blood eosinophils and the total serum IgE were insensitive markers for predicting the efficacy, which is compatible with previous data (Brightling et al., 2005).

Table 3 | Sensitivity, specificity, positive predictive values (PPVs), and negative predictive values (NPVs) at $\mathrm{FE}_{\mathrm{NO}}>35 \mathrm{ppb}$, atopy+, and combined with $\mathrm{FE}_{\mathrm{NO}}>35 \mathrm{ppb}$ and atopy+ for predicting $\mathrm{FEV}_{1}$ improvement greater than $200 \mathrm{~mL}$.

\begin{tabular}{|c|c|c|c|c|}
\hline Marker & Sensitivity (\%) & Specificity (\%) & PPV (\%) & NPV (\%) \\
\hline $\mathrm{FE}_{\mathrm{NO}}>35 \mathrm{ppb}$ & 80.0 & 66.7 & 57.1 & 85.7 \\
\hline Atopy+ & 60.0 & 88.9 & 75.0 & 80.0 \\
\hline
\end{tabular}


When $\mathrm{FE}_{\mathrm{NO}}>35 \mathrm{ppb}$ and/or atopy+ were combined, the sensitivity was 1.0 and the specificity was 0.56 for the subjects whose $\mathrm{FEV}_{1}$ was increased greater than $12 \%$ by FP/SAL combination treatment. This sensitivity was higher than the 0.6 when $\mathrm{FE}_{\mathrm{NO}}>35 \mathrm{ppb}$. Combining the measurement of $\mathrm{FE}_{\mathrm{NO}}$ and specific IgE may become a predictor of COPD patients who could benefit from ICS/LABA combination. More importantly, the specificity of a low (normal) $\mathrm{FE}_{\mathrm{NO}}(\leq 35 \mathrm{ppb}$ ) and atopy- was $100 \%$, indicating that a combining the measurement of $\mathrm{FE}_{\mathrm{NO}}$ and specific IgE would help the clinicians to avoid prescribing ICS/LABA treatment for non-responsive patients.

Inhaled corticosteroids/LABA combination therapy improved $\mathrm{FEV}_{1}$ by $130 \mathrm{~mL}$ from the baseline value, which is smaller than the results from previous studies (Mahler et al., 2002; Hanania et al., 2003; O'Donnell et al., 2006). This difference is probably due to the fact that the patients in our study already received treatment with muscarinic receptor antagonist. In fact, the degree of improvement in $\mathrm{FEV}_{1}$ in this study was similar to that reported previously when combined ICS/LABA was added for patients with COPD who had already been treated with tiotropium (Aaron et al., 2007; Cazzola et al., 2007; Welte et al., 2009). Furthermore, ICS/LABA combination therapy improved the slope of the single breath nitrogen washing curve which reflects ventilation heterogeneity (Buist and Ross, 1973), but did not decrease TLC and RV in the current study. O'Donnell et al. (2006) have shown that ICS/LABA combination therapy improved lung hyperinflation, but our data did not show reduced FRC and RV levels. We used the helium gas dilution method to assess the lung volume, whereas they measured the lung volume by body plethysmography. The discrepancy in the results is possibly due to this difference in the measurement of the lung volume.

There are several limitations in the current study. First, the value of $\mathrm{FE}_{\mathrm{NO}}$ was relatively higher than that of previously reported data in patients with COPD (Dummer et al., 2009; Lehtimaki et al., 2010). Lehtimaki et al. (2010) described that, when assessing the role of $\mathrm{FE}_{\mathrm{NO}}$ in $\mathrm{COPD}$, it is important to exclude asthma since concomitant asthma with more eosinophilic and steroid-sensitive inflammation might bias the results. In the present study, although we carefully excluded patients with asthma, as none of the subjects had a previous diagnosis or clinical history of asthma, atopic rhinitis, atopic dermatitis, or food allergy, we might not have been able to completely exclude COPD patients with an asthmatic component. Marsh et al. (2008) reported that asthma was a predominant COPD phenotype, being present in $55 \%$ of their subjects with COPD. Second, since this study consisted of very few subjects, further confirmation of the present results is needed in a large-scale randomized control trial. Finally, in the present study, we analyzed the efficacy of ICS/LABA only on pulmonary functions. Predictive factors for the effects on quality of life and inhibition of exacerbation, which are also important points of COPD pharmacotherapy, should be studied in the future.

In summary, we have shown that the increased $\mathrm{FE}_{\mathrm{NO}}$ levels and atopy appear to be useful predictors of ICS/LABA-mediated pulmonary function improvements in COPD.

\section{ACKNOWLEDGMENTS}

We thank Mr. Brent Bell for reading of manuscript.

\section{REFERENCES}

Aaron, S. D., Vandemheen, K. L., Fergusson, D., Maltais, F., Bourbeau, J., Goldstein, R., Balter, M., O’Donnell, D., Mcivor, A., Sharma, S., Bishop, G., Anthony, J., Cowie, R., Field, S., Hirsch, A., Hernandez, P., Rivington, R., Road, J., Hoffstein, V., Hodder, R., Marciniuk, D., Mccormack, D., Fox, G., Cox, G., Prins, H. B., Ford, G., Bleskie, D., Doucette, S., Mayers, I., Chapman, K., Zamel, N., and Fitzgerald, M. (2007). Tiotropium in combination with placebo, salmeterol, or fluticasone-salmeterol for treatment of chronic obstructive pulmonary disease: a randomized trial. Ann. Intern. Med. 146, 545-555. ATS/ERS. (2005). ATS/ERS recommendations for standardized procedures for the online, and offline measurement of exhaled lower respiratory nitric oxide, and nasal nitric oxide. Am. J. Respir. Crit. Care Med. 171, 912-930.

Brightling, C. E., Mckenna, S., Hargadon, B., Birring, S., Green, R., Siva, R., Berry, M., Parker, D., Monteiro, W., Pavord, I. D., and Bradding, P. (2005). Sputum eosinophilia and the short term response to inhaled mometasone in chronic obstructive pulmonary disease. Thorax 60, 193-198.

Brightling, C. E., Monteiro, W., Ward, R., Parker, D., Morgan, M. D., Wardlaw, A. J., and Pavord, I. D. (2000). Sputum eosinophilia and short-term response to prednisolone in chronic obstructive pulmonary disease: a randomised controlled trial. Lancet 356, 1480-1485.

Buist, A. S., and Ross, B. B. (1973). Predicted values for closing volumes using a modified single breath nitrogen test. Am. Rev. Respir. Dis. 107, 744-752.

Burge, P. S., Calverley, P. M., Jones, P. W., Spencer, S., Anderson, J. A., and Maslen, T. K. (2000). Randomised, double blind, placebo controlled study of fluticasone propionate in patients with moderate to severe chronic obstructive pulmonary disease: the ISOLDE trial. BMJ 320, 1297-1303.

Calverley, P., Pauwels, R., Vestbo, J., Jones, P., Pride, N., Gulsvik, A., Anderson, J., and Maden, C. (2003). Combined salmeterol and fluticasone in the treatment of chronic obstructive pulmonary disease: a randomised controlled trial. Lancet 361, 449-456.

Calverley, P. M., Anderson, J. A., Celli, B., Ferguson, G. T., Jenkins, C., Jones, P. W., Yates, J. C., and Vestbo, J. (2007). Salmeterol and fluticasone propionate and survival in chronic obstructive pulmonary disease. $N$. Engl. J. Med. 356, 775-789.

Cazzola, M., Ando, F., Santus, P., Ruggeri, P., Di Marco, F., Sanduzzi, A., and D'Amato, M. (2007). A pilot study to assess the effects of combining fluticasone propionate/salmeterol and tiotropium on the airflow obstruction of patients with severe-to-very severe COPD. Pulm. Pharmacol. Ther. 20, 556-561.

Celli, B. R., and MacNee, W. (2004). Standards for the diagnosis and treatment of patients with COPD: a summary of the ATS/ERS position paper. Eur. Respir. J. 23, 932-946.

Chanez, P., Vignola, A. M., O'Shaugnessy, T., Enander, I., Li, D., Jeffery, P. K., and Bousquet, J. (1997). Corticosteroid reversibility in COPD is related to features of asthma. Am. J. Respir. Crit. Care Med. 155, 1529-1534.
Drummond, M. B., Dasenbrook, E. C., Pitz, M. W., Murphy, D. J., and Fan, E. (2008). Inhaled corticosteroids in patients with stable chronic obstructive pulmonary disease: a systematic review and meta-analysis. JAMA 300, 2407-2416.

Dummer, J. F., Epton, M. J., Cowan, J. O., Cook, J. M., Condliffe, R., Landhuis, C. E., Smith, A. D., and Taylor, D. R. (2009). Predicting corticosteroid response in chronic obstructive pulmonary disease using exhaled nitric oxide. Am. J. Respir. Crit. Care Med. 180, 846-852.

Hanania, N. A., Darken, P., Horstman, D., Reisner, C., Lee, B., Davis, S., and Shah, T. (2003). The efficacy and safety of fluticasone propionate (250 microg)/salmeterol (50 microg) combined in the Diskus inhaler for the treatment of COPD. Chest 124, 834-843.

Jones, P. W., Willits, L. R., Burge, P. S., and Calverley, P. M. (2003). Disease severity and the effect of fluticasone propionate on chronic obstructive pulmonary disease exacerbations. Eur. Respir. J. 21, 68-73. 
Kunisaki, K. M., Rice, K. L., Janoff, E. N., Rector, T. S., and Niewoehner, D. E. (2008). Exhaled nitric oxide, systemic inflammation, and the spirometric response to inhaled fluticasone propionate in severe chronic obstructive pulmonary disease: a prospective study. Ther. Adv. Respir. Dis. 2, 55-64.

Lehtimaki, L., Kankaanranta, H., Saarelainen, S., Annila, I., Aine, T., Nieminen, R., and Moilanen, E. (2010). Bronchial nitric oxide is related to symptom relief during fluticasone treatment in COPD. Eur. Respir. J. $35,72-78$.

Leigh, R., Pizzichini, M. M., Morris, M. M., Maltais, F., Hargreave, F. E., and Pizzichini, E. (2006). Stable COPD: predicting benefit from high-dose inhaled corticosteroid treatment. Eur. Respir. J. 27, 964-971.

Lung Health Study Research Group. (2000). Effect of inhaled triamcinolone on the decline in pulmonary function in chronic obstructive pulmonary disease. N. Engl. J. Med. 343, 1902-1909.

Mahler, D. A., Wire, P., Horstman, D., Chang, C. N., Yates, J., Fischer, T., and Shah, T. (2002). Effectiveness of fluticasone propionate and salmeterol combination delivered via the Diskus device in the treatment of chronic obstructive pulmonary disease. Am. J. Respir. Crit. Care Med. 166, 1084-1091.

Malinovschi, A., Janson, C., Hogman, M., Rolla, G., Toren, K., Norback, D., and Olin, A. C. (2009). Both allergic and nonallergic asthma are associated with increased $\mathrm{FE}(\mathrm{NO})$ levels, but only in never-smokers. Allergy $64,55-61$.

Marsh, S. E., Travers, J., Weatherall, M., Williams, M. V., Aldington, S., Shirtcliffe, P. M., Hansell, A. L., Nowitz, M. R., Mcnaughton, A. A., Soriano, J. B., and Beasley, R. W. (2008). Proportional classifications of COPD phenotypes. Thorax 63, 761-767.

Matsunaga, K., Hirano, T., Kawayama, T., Tsuburai, T., Nagase, H., Aizawa, H., Akiyama, K., Ohta, K., and Ichinose, M. (2010). Reference ranges for exhaled nitric oxide fraction in healthy Japanese adult population. Allergol. Int. 59, 363-367.

McSharry, C. P., Mckay, I. C., Chaudhuri, R., Livingston, E., Fraser, I., and Thomson, N. C. (2005). Short and long-term effects of cigarette smoking independently influence exhaled nitric oxide concentration in asthma. J. Allergy Clin. Immunol. 116, 88-93.

O’Donnell, D. E., Sciurba, F., Celli, B. Mahler, D. A., Webb, K. A., Kalberg, C. J., and Knobil, K. (2006). Effect of fluticasone propionate/salmeterol on lung hyperinflation and exercise endurance in COPD. Chest 130, 647-656.

Pauwels, R. A., Lofdahl, C. G., Laitinen, L. A., Schouten, J. P., Postma, D. S., Pride, N. B., and Ohlsson, S. V. (1999). Long-term treatment with inhaled budesonide in persons with mild chronic obstructive pulmonary disease who continue smoking. European Respiratory Society study on chronic obstructive pulmonary disease. N. Engl. J. Med. 340, 1948-1953.

Pizzichini, E., Pizzichini, M. M., Gibson, P., Parameswaran, K., Gleich, G. J., Berman, L., Dolovich, J., and Hargreave, F. E. (1998). Sputum eosinophilia predicts benefit from prednisone in smokers with chronic obstructive bronchitis. Am. J. Respir. Crit. Care Med. 158, 1511-1517.

Rabe, K. F., Hurd, S., Anzueto, A. Barnes, P. J., Buist, S. A., Calverley, P., Fukuchi, Y., Jenkins, C., RodriguezRoisin, R., Van Weel, C., and Zielinski, J. (2007). Global strategy for the diagnosis, management, and prevention of chronic obstructive pulmonary disease: GOLD executive summary. Am. J. Respir. Crit. Care Med. 176, 532-555.

Rodrigo, G. J., Castro-Rodriguez, J. A., and Plaza, V. (2009). Safety and efficacy of combined longacting beta-agonists and inhaled corticosteroids vs long-acting betaagonists monotherapy for stable COPD: a systematic review. Chest 136, 1029-1038.

Schleich, F. N., Seidel, L., Sele, J., Manise, M., Quaedvlieg, V., Michils, A. and Louis, R. (2010). Exhaled nitric oxide thresholds associated with a sputum eosinophil count $\geq 3 \%$ in a cohort of unselected patients with asthma. Thorax 65, 1039-1044.

Singh, S., Amin, A. V., and Loke, Y. K. (2009). Long-term use of inhaled corticosteroids and the risk of pneumonia in chronic obstructive pulmonary disease: a meta-analysis. Arch. Intern. Med. 169, 219-229.

Spencer, S., Calverley, P. M., Burge, P. S., and Jones, P. W. (2004). Impact of preventing exacerbations on deterioration of health status in COPD. Eur. Respir. J. 23, 698-702.

Szafranski, W., Cukier, A., Ramirez, A. Menga, G., Sansores, R., Nahabedian, S., Peterson, S., and Olsson, H. (2003). Efficacy and safety of budesonide/formoterol in the management of chronic obstructive pulmonary disease. Eur. Respir. J. 21, 74-81.

Vestbo, J., Sorensen, T., Lange, P., Brix, A., Torre, P., and Viskum, K. (1999). Long-term effect of inhaled budesonide in mild and moderate chronic obstructive pulmonary disease: a randomised controlled trial. Lancet 353, 1819-1823.

Wedzicha, J. A., Calverley, P. M., Seemungal, T. A., Hagan, G., Ansari, Z., and Stockley, R. A. (2008). The prevention of chronic obstructive pulmonary disease exacerbations by salmeterol/fluticasone propionate or tiotropium bromide. Am. J. Respir. Crit. Care Med. 177, 19-26.
Welte, T., Miravitlles, M., Hernandez, P., Eriksson, G., Peterson, S., Polanowski, T., and Kessler, R. (2009). Efficacy and tolerability of budesonide/formoterol added to tiotropium in patients with chronic obstructive pulmonary disease. Am. J. Respir. Crit. Care Med. 180, 741-750.

Zietkowski, Z., Kucharewicz, I., and Bodzenta-Lukaszyk, A. (2005). The influence of inhaled corticosteroids on exhaled nitric oxide in stable chronic obstructive pulmonary disease. Respir. Med. 99, 816-824.

Conflict of Interest Statement: Masakazu Ichinose has served on Scientific Advisory Boards for AstraZeneca, GlaxoSmithKline KK, Nippon Boehringer Ingelheim, and Novartis Pharma KK, and has received unrestricted grant from GlaxoSmithKline KK, Nippon Boehringer Ingelheim, Abbott Japan Co, and Novartis Pharma KK.

Received: 30 May 2011; accepted: 02 July 2011; published online: 18 July 2011. Citation: Akamatsu K, Matsunaga K, Sugiura H, Koarai A, Hirano T, Minakata $Y$ and Ichinose $M$ (2011) Improvement of airflow limitation by fluticasone propionate/salmeterol in chronic obstructive pulmonary disease: what is the specific marker? Front. Pharmacol. 2:36. doi: 10.3389/fphar.2011.00036

This article was submitted to Frontiers in Respiratory Pharmacology, a specialty of Frontiers in Pharmacology.

Copyright (c) 2011 Akamatsu, Matsunaga, Sugiura, Koarai, Hirano, Minakata and Ichinose. This is an open-access article subject to a nonexclusive license between the authors and Frontiers Media SA, which permits use, distribution and reproduction in other forums, provided the original authors and source are credited and other Frontiers conditions are complied with. 